\title{
Chiefs, Kings, and Patrons Leadership and Social Logics in the Beginnings of Ancient Egypt
}

\author{
Marcelo CAMPAGNO
}

\begin{abstract}
This article analyses different types of sociopolitical leadership in Ancient Egypt from the fourth to the third millennium BC linked with the social logics of kinship, the state, and patronage. It is suggested that such logics can be considered in terms of coexistence rather than in terms of sequence. In particular, the use of the concept of patronage is emphasised, not just for periods of state crisis but also-in connection with the concepts of kinship and the state-to think about the earliest epochs of Egyptian history.
\end{abstract}

Este artículo propone una consideración de las diversas formas de liderazgo sociopolítico en el Antiguo Egipto del IV y el III milenio a.C. en relación con las lógicas sociales del parentesco, del Estado y del patronazgo. Se sugiere que tales lógicas pueden pensarse en términos de coexistencia más que de secuencia. En particular, se enfatiza la posibilidad de emplear el concepto de patronazgo no solamente para los períodos de crisis estatal sino, en articulación con los conceptos de parentesco y de Estado, para pensar las épocas más tempranas de la historia egipcia.

Keywords: patronage, kinship, state, leadership, social logics.

Palabras clave: patronazgo, parentesco, Estado, liderazgo, lógicas sociales.

\section{Historical} analyses are sometimes enriched through the incorporation of concepts forged in very different contexts. Depending on the efficiency of the articulation, these additions may contribute to the theoretical thinking of different historical situations. In tune with this expectation, here I would like to propose the use of the concept of patronage to expand the possibilities of thinking about the issue of the leadership-or the forms of sociopolitical prevalence-in Ancient Egypt's early stages. Strictly speaking, the concept is not unknown in Egyptology; however, in general, it is not used for the initial periods of Egyptian history but rather for later times. I suspect there are reasons for this absence, and at the end of this article I will try to suggest an interpretation. But before that, to focus on this issue, I would like to make two preliminary reflections.

The first one is related to the provenance of the theoretical concepts used to think about ancient societies. Broadly speaking, theoretical thinking on ancient societies has two main sources: a more anthropological source, which is usually recognised in studies about the so-called prehistoric societies (and also in the passage from these ones to the "historical" societies), and which provides concepts such as kinship, chiefdoms, and state; and a more sociological source, which offers other kinds of concepts, such

$$
\begin{gathered}
\text { TdE } 7 \text { (2016) - Páginas: 9-22 } \\
\text { Recepción: 30/10/2016 - Admisión: 17/11/2016 } \\
\text { Marcelo Campagno - mcampagno@gmail.com } \\
\text { Consejo Nacional de Investigaciones Científicas y Técnicas / Universidad de Buenos Aires / Argentina }
\end{gathered}
$$


as patrimonialism, household, and the patron-client relationship. As for Ancient Egypt, the anthropological source is much more easily recognisable with regard to the earliest stages: it is the type of concepts that, regardless of specific approaches, prevails in the analyses about the "origin of the state" . In turn, the sociological source is more apparent in analyses of later periods, particularly the First Intermediate Period, for which concepts such as patronage ${ }^{2}$ and patrimonialism $^{3}$ have been considered. These sources imply very different theoretical traditions; however, nothing forces to choose between one or the other.

The second preliminary reflection that I would like to briefly introduce is the general theoretical perspective from which I try to consider this issue, focusing on what I call logics of social organisation. In fact, from my point of view, the utility of the concept of patronage for the study of the early periods of Egyptian history is related to the possibility of thinking the preponderance of certain social logics in the structuration of any historical situation. I call "logic" to the effect of articulation of the practices that compose any situation, which implies the predominance of a specific practice that provides the "code" for the functioning of the social dynamic ${ }^{4}$. I think we can consider three main social logics to the purposes of the present analysis. The first one is what I call logic of kinship, which is based on reciprocity principles or, as Marshall Sahlins has pointed out ${ }^{5}$, on the "mutuality of being". A second logic is the logic of the state, based on the dominant presence of the legitimate monopoly of coercion $^{6}$. And a third logic, which I define as logic of patronage and here we will discuss more in depth, which prima facie seems to combine characteristics of both kinship and the state but produces a specific kind of social articulation, based on a relationship of "asymmetrical reciprocity"7. I think each of these logics determine scenarios that, from a socio-political point of view, are characterised through very different kinds of social bond, which, in turn, produce very different forms of leadership.

\section{Kinship and the State}

I will briefly refer to the logics of kinship and the state, to then focus on the logic of patronage in a more detailed way. With regards to kinship, I would say, first of all, that it is a logic of social organisation whose presence goes back to pre-state times. It is the kind of logic that can be more easily recognised in the organisation of village communities, as they are archaeologically evident from Predynastic times. It is also a kind of logic that, while subordinated to others social principles, continues

1 See, for instance: Pérez Largacha, 1993; Wilkinson, 1996; Maisels, 1999; Campagno, 2002; Midant-Reynes, 2003; Wenke, 2009; Köhler, 2010. See: Assmann, 2002; Franke, 2006; Willems, 2010; Eyre, 2011; Moreno García, 2013.

Lehner, 2000.

Campagno, 2006: 17 .

Sahlins, 2011: 2-3.

See Campagno, 2002: 15-16.

Orenstein, 1980; see Westbrook, 2005: 211. 
in state times, as can be noticed in different social contexts, such as the state elite inner articulation, and the structuration of peasant communities once the state emerges. The forms of leadership within societies organised by the kinship logic are mainly characterised by the prestige of the chiefs. The anthropologist Pierre Clastres, for example, has emphasised the strong difference between the forms of leadership that are typical of these societies and the ones that can be seen in state times, in such a way that a non-state leader is not simply a small-scale king-a king who would have a modest power but a power anyway-but someone whose preponderance is unrelated to the issue of power, and connected with the general dynamic of kinship reciprocity ${ }^{8}$.

There are examples of this kind of leadership, mainly from Predynastic iconographic sources, especially from Naqada I onwards. Since then, the representation of some individuals are highlighted by their size, their dresses, the objects they brand, and gestures that could involve some type of ritual practices, in contrast with the images of others characters, which are represented of a smaller size, devoid of those attributes, and in more passive positions. Regardless of the specific meaning of these scenes, it seems clear that, in them, the former were deliberately detached from the latter. Such kind of representations can clearly be seen in the decoration of wares found in (or related to) funerary contexts, both from Naqada I-for example, the vessels found in tombs U-239 and $\mathrm{U}-415$ of the Cemetery $\mathrm{U}$ at $\mathrm{Abydos}^{9}$, and the vessel $\mathrm{E}_{3} \mathrm{OO} 2$ of Brussels ${ }^{10}$-and early Naqada II $^{11}$. The same kind of characters is also represented in the rock art, both in the Eastern ${ }^{12}$ and in the Western ${ }^{13}$ deserts. More indirectly, we could infer this type of leadership from the fact that some Predynastic tombs contain objects such as sceptres and mace heads, whose role probably would not have been utilitarian but linked to ostentation, as a sort of leadership regalia ${ }^{14}$. Within the framework of Naqada I-II cemeteries, Predynastic leadership can also be considered regarding some tombs with greater quantity and quality of funerary goods, or with more distant origins, which always constitute a minority within the general group of burials of any given locality. These tombs can be seen as reflecting the social context for the non-state figures of leadership ${ }^{15}$.

Once the state emerges, some line of continuity can be traced between this type of pre-state leadership and the village leadership during state times. Thus, for example, the $h q 3 w n w w t$, which are represented in the mastaba of Ti at Saqqara, and are referred to in the decrees of Koptos, surely imply a form of local leadership that takes place in state times but it is not derived directly from the

8 Clastres, 1981: 146-149; see Campagno, 2014b: 18.

9 Dreyer et al., 1998: 84, 111-115; Dreyer et al., 2003: 74-75, 80-82.

10 Vandier, 1952: 287; Hendrickx, 1998: 204-207.

11 cf. Vandier, 1952: 286-288, 352-353; Midant-Reynes, 1992: 165-167, 180-182.

12 Redford and Redford, 1989: 3-50; Wilkinson, 2000: 158-165.

13 Huard and Leclant, 1980: 368, 456, 470; Barta and Frouz, 2010: 40, 68, 92.

14 See Campagno, 2002: 153-155.

15 See Campagno, 2002: 151-153. 
state administration ${ }^{16}$. Indeed, the iconography shows the state officials addressing these village headmen in clearly coercive terms, as village representatives, so their prevalence at the local level seems related to the continuity of the village dynamics of social organisation rather than to an external imposition from the state order. Usually we lose sight of these forms of local leadership, because the dominant perception of the historical process, as it is proposed by evolutionist theories, tends to go from the chief to the king, in an ever-ascending direction, so that the focus is placed on the king and his officials and no longer on village leaders, as if the latter disappeared once there is a state organisation.

As for the state logic, it takes place within the context of a deep process of change that began during the fourth millennium $\mathrm{BC}$, implying a notorious leap of scale with regards to local communities, that generates a qualitatively different social dynamic extended in a much wider territory. And the forms of leadership that correspond to the state, unlike what happens inside communities, are related to the capacity of the state to concentrate and exercise the legitimate monopoly of coercion. The state logic introduces a strongly vertical social bond, which implies the imposition of those who exert coercion over the rest of society and the creation of an-until then-unthinkable capacity of transformation in very different contexts ${ }^{17}$. Regarding the evidence, the state logic can be more easily appreciated through the early iconography that describes different coercive actions taken by the state. In the decorated wall of Tomb 100 of Hierakonpolis ${ }^{18}$, for example, a scene of the massacre of the enemy is included ${ }^{19}$, which perhaps refers to nearby enemies but foreign with respect to the area under the control of the town. Later, this same kind of massacre scenes is invariably projected to the inhabitants of the regions beyond the state realm, that is, towards Asiatics, Nubians and Libyans ${ }^{20}$.

But it is not only a matter of coercion towards the outside: other scenes seem to involve some coercion inwards. An example of this is found in two inscriptions on vessels of king Khasekhem (Second Dynasty), where the goddess Nekhbet seems to carry a ring before the king, with the word $b \check{s}$, "rebel" Another example can be seen in the iconography of Scorpion's mace head ${ }^{22}$, in whose upper register some lapwings are represented hanged from a group of royal standards. The meaning of these birds has been much discussed, but it is probably associated to the rhyt, that is, the subordinated population, as such population is symbolised in later times. The same birds are depicted on a statue base of king Netjerkhet (Third Dynasty), where these rhyt appear in relation to

16 Moreno García, 1999: 229-232; 2001; 2004: 89-91.

17 Campagno, 2013a.

18 Quibell and Green, 1902: pl. 76.

19 Hall, 1986: 3-7; Gundlach, 1988: 252-255; Cervelló, 1996: 206-208.

20 Kohler, 2002: 504; Wilkinson, 2002: 518.

21 Quibell, 19oo: pl. 36; Wilkinson, 1999: 91-92.

22 Quibell, 1900: pl. 25; Baines, 1995: 119. 
the Nine Bows, which symbolise the foreign world, both represented at the feet of the king, seeming to imply all the people whom the king rules ${ }^{23}$. In fact, those $h q 3 w$ nwwt mentioned regarding the issue of village leadership can also be considered at this point, as representatives of the population subordinated to the state: in the scenes depicted in the mastabas of Old Kingdom high officials, such as those of Ti and Mereruka, they appear being beaten before the state officials, which highlight the explicitly coercive attitude that the state exerts on those figures of village leadership.

\section{Patronage}

Now I would like to analyse here in more detail a third social logic which operates in connection to those of kinship and the state: the logic of patronage. First of all, two features that characterise the specificity of patronage bonds will be considered. On the one hand, unlike kinship-which produces a network of social relations-and the state-which rather implies a force that extends itself over all subjects in a generalised way-patronage involves a type of dyadic relations, i.e., personal links between patron and client. A patron can certainly have many clients but he traces a specific, direct relationship with each of them. On the other hand, patronage is characterised, as al- ready noted, by a bond of "asymmetrical reciprocity", which implies a kind of gifts and counter gifts, where the patron normally gives some kind of protection or access to resources to clients, and the client has to give his loyalty to the patron in return. It is a kind of reciprocity, but which obviously implies a notorious disparity between both parties ${ }^{24}$. This is interesting regarding the forms of leadership that patronage determines, because patronage produces an evident bond of subordination of the client to the patron, but such a bond does not involve the possession of the legitimate monopoly of coercion in the patron's hands, as it happens with the bond of subordination that the state logic produces. This implies possibilities that could not happen within the framework of the state logic as, for example, that a client can transfer his loyalty from one patron to another one, even though the word of the patron always will be "less than an order but more than an advice" 25 and therefore the client's real possibilities to manoeuvre can be, depending on the contexts, severely restricted.

As I pointed out above and in other works ${ }^{26}$, the question of patronage is not absent in the Egyptological field to understand some periods of the Egyptian history. In this sense, it is worthwhile to considergiven the academic hierarchy of its authoran observation of Jan Assmann about the "emergence of a new social type" 27 with

23 Firth and Quibell, 1935, I: 14, 65-66 and II: pl. 58; Cervelló, 2009: 82.

24 See: Powell, 1970: 412; Eisenstadt and Roniger, 1984: 251-263; Gellner and Waterbury, 1977: 4; Campagno, 2009: 348-349.

25 Mommsen, 1985, VII: 232.

26 Campagno, 2013c and 2014a.

27 Assmann, 2002: 50. 
regards to the figure of the patron, which would take place during the First Intermediate Period. Assmann's analysis focuses basically on the Autobiography of Ankhtifi, nomarch of Hierakonpolis at the beginning of the Ninth Dynasty. In his perception, within the crisis of the late Old Kingdom state dynamics, it emerges as a new kind of interpersonal bond, linked to the issue of patronage. Indeed, the Autobiography of Ankhtifi is an extraordinary source to see this kind of issue. I mention here just a couple of the many statements that can be drawn from this text and that Assmann considers in his work. In one of them, Ankhtifi asserts that nothing bad happened to those he protected, but the opposite happened to any "ignorant $(\mathrm{hm})$ and wretched (hwrw) who was against me" ${ }^{28}$, ignoring the advice of the nomarch. This suggests that Ankhtifi established a selective relation with the population in his nome, protecting some individuals and unprotecting others according to the loyalty they have with the nomarch. Similarly, Ankhtifi boasts about having given aid to the needy, as well as being "the beginning and the end of the people", i.e., someone who acts "by his deep determination", becoming himself "a hero (t $3 y$ ) without peer"29. The Autobiography of Ankhtifi is full of this type of rhetoric, and the same can be said about other autobiographies of other potentates of the time $3^{\circ}$. Beyond the texts, the funerary space organisation of
Ankhtifi's tomb complex can also be related to patronage. In front of the tomb of the nomarch, there are a number of small subsidiary tombs, which Ludwig Morenz ${ }^{31}$ considers as probable graves of the individuals mentioned in Ankhtifi's autobiography as d $3 m w n m h-j b$, "reliable troops". These individuals integrated a small military group led by Ankhtifi, who established with them a personal and asymmetrical tie that would be expressed, in funerary terms, in the proximity between the great tomb of the nomarch and the small graves of his followers ${ }^{32}$.

What I want to emphasise at this point is the fact that these two types of sources-autobiographical texts and subsidiary tombscan be recognised in previous times, so that perhaps the importance of patronage in Ancient Egypt can be considered not only when the state power weakens but also in times in which it is strong. With respect to the textual evidence, many of Ankhtifi's statements in his autobiography have an echo in the autobiographies of the Old Kingdom high officials. For instance, the Autobiography of Qar, nomarch of Edfu during the Sixth Dynasty 33 , includes the kind of statements which are very frequent in Old Kingdom autobiographies and which are also present in the text of Ankhtifi. Such statements refer to the fact of having given bread to the hungry, water to the thirsty, clothing the naked, a boat to the boatless, etc. ${ }^{34}$. While the recurrence of such claims in the funerary autobi-

28 Vandier, 1950: 179-180.

29 Vandier, 1950: 171.

30 See, for example, that of Henqu of Deir el-Gabrawi: Schenkel, 1965: 41.

31 Morenz, 2009-2010: 190.

32 See Godenho, 2007: 161-166.

33 Sethe, 1933: 251-255; el-Khadragy, 2002; Strudwick, 2005: 342-344.

34 Coulon, 1997; Kloth, 2002. 
ographies suggests a stereotyped use, what matters here is not if they reflect the truth of what actually happened but the claim itself, as it implies a type of action that is not deducted from the state duties of the official and that seems to evoke another kind of relationship. A state official is not compelled, by way of the state logic, to perform such actions. These claims seem to characterise a type of individual with enough capacity to help those in need, and one may wonder if the needy would not be obliged to reciprocate, at the very least, with their loyalty, a key component of patronage practices.

Without going any further, if these claims appear as too stereotyped, there is another passage from the same autobiography, in which Qar points out, more specifically, that he pay debts of someone overwhelmed by a loan $(t 3 b t)$ with goods from his own house ${ }^{35}$. Therefore, it was not a state policy: Qar, in person, pay those debts with his own goods. Again, a scenario related to the logic of patronage can be noticed, in which a powerful individual protects the needy, who, in turn, should have to give his loyalty to the one that helped him. The remarkable point is that Qar exerts patronage over the needy in parallel to the functions he performs as an official of the Egyptian state. As for the subsidiary tombs, the existence of small burials surrounding large and well-endowed tombs is known throughout the third millennium BC, not only for the end of that period. For instance, the organisation of the funerary space in Old Kingdom elite cemeteries at Naga ed-Der, Dendera, Abydos, follows this pattern ${ }^{3}$. Different researchers have interpreted such a pattern as a sort of funerary evocation of the households of local potentates, which are also represented in the decoration of their tombs, where the landlord appears surrounded by his family but also by larger groups of individuals related to him through bonds of personal subordination ${ }^{37}$.

If we go further back in time, to the beginning of third millennium BC, First Dynasty sources, both textual evidence and funerary archaeology, show some hints of an equivalent situation. Let us consider, in this sense, the stela of Merka ${ }^{3}$, a high official during king Qaa's time. As a high state official, Merka exerts different tasks both within the royal palace-i.e., in the context of the elite's internal dynamics-and towards outside for instance, as $\underline{d} \mathbf{d}-m r$ zmjt (administrator of desert areas) and as hrp (inspector) who controls some localities, all of which implies that Merka has a clear profile as a state agent. However, Mer$\mathrm{ka}$ is something more. He highlights in his stela that he was a jrj-p $p^{`}$, a title which refers to another kind of dynamics, implying his membership to a very restricted group $\left(p^{\imath} t\right)$ related to the king, probably through kinship ties. And most important, for the purposes we are considering here, Merka is also a šms $n z w t$, that is, a "follower of the king". This is very interesting because such an "honorific" title seems to evoke, in the absence of a specific function, a type of relationship of personal proximity and subordination to the figure of the king: a šms is someone who is close to the king, but following him. In such

35 Sethe, 1933: 254-245; el-Khadragy, 2002: 210-211.

36 Reisner, 1932: 187; Richards, 2005: 134; Seidlmayer, 1990: 408-409.

37 Baines and Lacovara, 2002: 9; Doxey, 2009: 2; Snape, 2011: 100.

38 Emery, 1958: pl. 39; Helck, 1987: 230-236; Wilkinson, 1999: 148-149. 
a way, the relationship between a šms and the king can clearly be interpreted in terms of patronage.

As for the funerary evidence, the space organisation in the royal or elite cemeteries of the First Dynasty at Abydos and Saqqara $^{39}$, but also in Giza, Abu Rawash, and Tarkhan ${ }^{40}$, offers many examples of subsidiary graves surrounding the large tombs of the king or other members of the elite. Of course, it cannot be inferred that every subsidiary tomb evokes a bond of patronage because these tombs could be occupied by individuals who might express a wide variety of social conditions, from nobles to servants $^{41}$. However, what is interesting to note is that, from the nobles who occupied the highest social positions to the servants who occupied the lowest ones, all of them had a kind of specific, personal, relationship with the king, and therefore, some of the individuals buried there could have been related to the monarch through a link of patronage.

In this sense, the stela of Sabef ${ }^{42}$ is worth considering because the place in which it was erected is known, and therefore, both the textual and the funerary aspects to think about the issue of patronage in this early time are expressed. As in the case of Merka, Sabef is also referred to as a high state official, who carries out a series of tasks mainly related to the internal administration of the Palace, but who is also a smr-pr nzwt, a "friend/colleague of the King's House". This condition of smr is interesting because it seems to point to the same kind of relationship connected to royal patronage. Šms and smr-(pr) nzwt-and also, in somewhat later contexts, the title of $r h-n z w t$, "King's acquaintance"-are titles that have a common denominator: the reference to the proximity with respect to the king, a proximity that is interpretable in terms of subordination to the monarch ${ }^{43}$. This reference has to be related to the fact that the stela of Sabef was placed in a subsidiary grave inside king Qaa's complex at Abydos. In this way, the specific relationship that links Sabef to king Qaa that can be seen in the former's title of $s m r$ has a funerary correlation in the disposition of the graves of one and the other in the Royal Cemetery of Abydos, both testimonies suggesting a relationship of patronage.

A last example, which allows considering the issue of patronage even earlier, in the fourth millennium $\mathrm{BC}$, is related to some recent findings in the Cemetery HK6 of Hierakonpolis. Tomb 16 of this cemetery stands out for the fact that it is surrounded by a remarkable group of more than a dozen tombs of individuals, as well as others occupied by animals, reflecting an organisation of the funerary space similar to that which is known for later times, and suggesting a link of proximity between the occupants of the subsidiary tombs and the individual buried in Tomb $16^{44}$. In fact, Renée Friedman has proposed an interpretation of this group of tombs very compatible to what we are suggesting here, in the sense that the Tomb 16 and the smaller graves that surround it "form a complex that we tentative

39 Engel, 2008; Bestock, 2008; Hendrickx, 2008.

40 Vaudou, 2008; Reisner, 1936.

41 Vaudou, 2008: 152-158.

42 Petrie, 1900: pl. xxx-xxxi; Helck, 1987: 228.

43 Cf. Jones, 2000: 327-328, 891-896, 991-992.

44 Friedman et al., 2011: 159-162. 
reconstruct as imitating the owners earthly residence with household members holding their place in death as they did in life" 45 . Thus, this organisation of the funerary space could be understood as reflecting the organisation of a household. And precisely, the household, inasmuch as it implies a social group that includes a kin-based core but it is also integrated by individuals subordinated to the household's head, is clearly interpretable as an organisation based on the logic of patronage $e^{4}$. This is interesting because it would imply the possibility of thinking about patronage within the context of transformations that Hierakonpolis was experiencing in those early times, linked to the general process of the emergence of the state.

\section{Conclusions}

To conclude, I would like to point out two issues. The first one refers to the connection between forms of leadership and social logics. If we can relate any specific form of leadership to the social logic of the situation in which that leadership exists as such, we can notice the heterogeneity of modes of sociopolitical prevalence, which in turn allows taking distance from the preconception that assumes that leadership always implies power and the same type of power. A Predynastic village leader, for example, does not prefigure the kings or high officials of state times because the logic of kinship enables a mode of prevalence by way of prestige, but the prestigious one is never provided with the monopoly of legitimate coercion, which is key to understand the state leadership. Similarly, the capacity of general imposition that those kings and high officials have within the framework of the state logic is different from the way in which a patron prevails over his clients within the context of a household, where the patron has economic and/or political means to ensure the subordination of each of his clients but lacks the coercive capacity which is related to the state. Thus, there is not a sort of "power race" in which the village leader would have little power, the patron would have something more, and the king would have much more, but different modes of prevalence according to different logics of social organisation.

The second issue that I would like to point out as a consequence of this analysis indicates that these social logics that we have considered here-patronage as well as kinship and the state-are not necessarily consecutive but rather simultaneous. Of course, some logics may exist before others. For example, with regard to kinship, we can assume its existence from very remote times. But once the other logics, linked to the state and eventually to patronage, emerge, they can coexist in a same historical context. It is not a sequence that has to necessarily go from kinship to the state, and then only the state logic rules, and when the state is in crisis then appears the logic of patronage. They are dynamics that can coexist in such a way that, at the same time, individuals or groups may be expressing different social relations in accordance with the context that is analysed ${ }^{47}$. In this sense, an example as the one we saw about Qar of Edfu allows to notice that Qar is, at

45 Friedman, 2014.

46 Eyre, 1987: 40; Lehner, 200o: 283-286; Baines, 2009-2010: 127-136; Moreno García, 2012.

47 See Campagno, 2013d. 
the same time, a high state official regarding the orders he receives from the king and he has to execute in his nome, but also a kin with respect to the members of his family and the local elite in Edfu, and a patron with respect to other individuals to whom, for example, he has rescued from certain debts. Similarly, at the end of the First Dynasty, king Qaa can exercise the political power as a monarch, and at the same time be a kin within the royal family, and a patron with respect to certain individuals with whom he maintains a personal bond, as is the case of Sabef.

Why is so usual to think about this issue in terms of sequence rather than in terms of coexistence? I think this is so because there is an induction to think in this way as a result of the prevalence of evolutionism as current ideology. Evolutionism tends to interpret historical processes from a biological analogy: a "society" works as a living being and, as such, it is a homogeneous being that grows. In this context, there is no room to think of heterogeneous social logics that coexist without a "plan", as well as there is no place for thinking about emergences or dissolutions of practices that do not follow a fairly predictable course of development. Thus, the state can be seen as an evolution of village societies organised by kinship at the end of the fourth millennium $\mathrm{BC}$, and a millennium later, patronage can be considered as a degradation-an "involution" - of the state within the context of late Old Kingdom "crisis". But if we do not follow this way of understanding the socio-historical processes, it is possible to think about the existence of different social logics that, at some point, can be connected or disconnected, can emerge or dissolve themselves, but which do not constitute a sequence which must necessarily lead from a stage to the next one ${ }^{48}$.

In this sense, I think that the possibility of incorporating the concept of patronage not only to think about a stage of "crisis" of the state but also to understand historical dynamics of larger scale may be useful to analyse the initial periods of the Egyptian history. In the same way in which the concepts of kinship and the state suggest two very different social logics, the link between these concepts and the concept of patronage allows to recognise a different social logic, articulated to the other two logics. In this way, the diversity of modes of leadership that we see in these early times can be directly related to the different social logics that are behind them. Thus, the differences between a village leader, a state official and a patron of a household are not quantitative but qualitative. More in general, it is worth trying to introduce these types of theoretical issues in the field of Egyptology because the possibility of having more theoretical tools allows for a deep understanding of social bonds in Ancient Egypt. In the absence of such tools, we tend to think spontaneously, based in our "common sense" that, ultimately, use to reflect other outdated theoretical perspectives, such as those hammered from the old forge of evolutionism.

\section{Bibliography}

Assmann, J.

2002 The Mind of Egypt. History and Meaning in the Time of the Pharaohs. Cambridge-Massachusetts, London (original edition 1996).

48 Campagno, 2013b. 
BAINES, J.

1995 "Origins of Egyptian Kingship", in: D. O'Connor and D.P. Silverman (eds.): $A n$ cient Egyptian Kingship, Leiden: 95-156.

2009-2010 "Modelling the integration of elite and other social groups in Old Kingdom Egypt", in: J.C. Moreno García (ed.): Élites et pouvoir en Égypte ancienne, (Cahiers de Recherches de l'Institut de Papyrologie et d'Égyptologie de Lille 28), Lille: 117-144.

Baines, J.; Lacovara, P.

2002 "Burial and the dead in ancient Egyptian society. Respect, formalism, neglect", Fournal of Social Archaeology 2 (1): 5-36.

BÁrta, M.; Frouz, M.

2010 Swimmers in the Sand. On the Neolithic Origins of Ancient Egyptian Mythology and Symbolism. Praha.

Bestock, L.D.

2008 "The Early Dynastic Enclosures of Abydos", Archéo-Nil 18: 42-59.

Campagno, $\mathrm{M}$.

2002 De los jefes-parientes a los reyes-dioses. Surgimiento y consolidación del Estado en el antiguo Egipto. (Aula Egyptiaca Studia 3). Barcelona.

2006 "De los modos de organización social en el Antiguo Egipto: Lógica de parentesco, lógica de Estado", in: M. Campagno, (ed.): Estudios sobre parentesco y Estado en el antiguo Egipto, Buenos Aires: 15-50.

2009 "Parentesco, patronazgo y Estado en las sociedades antiguas: A modo de introducción", in: M. Campagno, (ed.): Parentesco, patronazgo y Estado en las sociedades antiguas, Buenos Aires: 7-24.

2013a "Coercion, creation, intervention: Three capacities of the early Egyptian state", in: E. Frood and A. McDonald (eds.): Decorum and experience: Essays in ancient culture for fohn Baines, Oxford: 214-219.

2013b "De crisis y colapsos. Problemas de historiografía e historia del valle del Nilo hacia finales del III milenio a.C.", in: Calidoscopio del pasado. XIV fornadas Interescuelas/ Departamentos de Historia, Mendoza: Universidad Nacional de Cuyo, http://jornadas.interescuelashistoria.org/.
2013C "Del patronazgo y otras lógicas de organización social en el Valle del Nilo durante el III milenio a.C.", in: M. Campagno, J. Gallego and C. García Mac Gaw (eds.): Rapports de subordination personnelle et pouvoir politique dans la Méditerranée et au-delà. XXXIVe Colloque international du GIREA - III Coloquio Internacional del PEFSCEA, Besançon: 53-70.

2013d "Lógicas coexistentes: lo estatal, lo parental y lo patronal en la escena sociopolítica del Valle del Nilo del IV al III milenio a.C.", in: C. Di Bennardis, E. Ravenna and I. Milevski (eds.): Diversidad de formaciones políticas en Mesopotamia y el Cercano Oriente. Organización interna y relaciones interregionales en la Edad del Bronce, (Barcino Orientalia Monographica 1), Barcelona: 147-162.

2014a "Patronage and Other Logics of Social organization in Ancient Egypt during the IIIrd Millennium BC", Journal of Egyptian History 7: 1-33.

2014b "Pierre Clastres, las sociedades contra el Estado y el mundo antiguo", in: M. Campagno, (ed.): Pierre Clastres y las sociedades antiguas, Buenos Aires: 7-34.

Cervelló Autuori, J.

1996 Egipto y África. Origen de la civilización y la monarquía faraónicas en su contexto africano. (Aula Orientalis-Supplementa 13). Sabadell.

2009 "El rey ritualista. Reflexiones sobre la iconografía del festival de Sed egipcio desde el Predinástico tardío hasta fines del Reino Antiguo", in: M. Campagno, J. Gallego and C. García Mac Gaw (eds.): Política y religión en el Mediterráneo Antiguo, Buenos Aires: 61-102.

Clastres, P.

1981 Investigaciones en antropología política. Barcelona (original edition 1980).

Coulon, L.

1997 "Véracité et rhétorique dans les autobiographies égyptiennes de la Première Période Intermédiaire", Bulletin de l'Institut Français d'Archéologie Orientale 97: 109-138.

Doxey, D.M.

2009 "The Nomarch as Ruler: Provincial necropoleis of the Old and Middle Kingdoms", in: R. Gundlach and J.H. Taylor, (eds.): 
Egyptian Royal Residences. $4^{\text {th }}$ Symposium on Egyptian Royal ideology, London, fune, $1^{\text {st }}$ $5^{\text {th }}$ 2004, (Königtum, Staat und Gesellschaft. Früher Hochkulturen 4.1), Wiesbaden: 1-11.

Dreyer, G.; Hartung, U.; Hikade, T.; Köhler, E.C.; Müller, V.; Pumpenpeier, F. 1998 "Umm el-Qaab. Nachuntersuchungen im frühzeitlichen Königsfriedhof. 9./10. Vorbericht", Mitteilungen des Deutschen Archäologischen Instituts Abteilung Kairo 54: 77-167.

Dreyer, G.; Hartmann, R., Hartung, U., Hikade, T., Köpp, H., LaGher, C., Müller, V., Nerlich, A.; Zink, A.

2003 "Umm el-Qaab. Nachuntersuchungen im frühzeitlichen Königsfriedhof. 13./14./15. Vorbericht", Mitteilungen des Deutschen Archäologischen Instituts Abteilung Kairo 59: $67-138$.

Eisenstadt, S.N.; Roniger, L.

1984 Patrons, Clients and Friends. Interpersonal Relations and the Structure of Trust in Society. Cambridge.

El-Khadragy, M.

2002 "The Edfu Offering Niche of Qar in the Cairo Museum", Studien zur Altägyptischen Kultur 30: 203-228.

EMERY, W.

$195^{8}$ Great Tombs of the First Dynasty, vol. III. London.

ENGEL, E.M.

2008 "The Royal Tombs at Umm el-Qaab", Archéo-Nil 18: 30-41.

Eyre, Ch.J.

1987 "Work and the Organisation of Work in the Old Kingdom", in: M. Powell (ed.): Labor in Ancient Near East, New Haven: 5-47.

2011 "Patronage, power, and corruption in pharaonic Egypt", International fournal of Public Administration 34: 701-711.

Firth, C.M.; Quibell, J.E.

1935 Excavations at Saqqara. The Step Pyramid, 2 vols. Cairo.
Franke, D.

2006 "Fürsorge und Patronat in der Ersten Zwischenzeit und im Mittleren Reich", Studien zur Altägyptischen Kultur 34: 159-185.

FRIEDMAN, R.F.

2014 "HK6: the Elite Predynastic and Early Dynastic cemetery", in: http://www. hierakonpolis-online.org/index.php/ explore-the-predynastic-cemeteries/ hk6-elite-cemetery; last access: June 18th 2014 .

Friedman, R.F.; Van Neer, W.; Linseele, V.

2011 "The elite Predynastic cemetery at Hierakonpolis: 2009-2010 update", in: R.F. Friedman and P.N. Fiske (eds.): Egypt at its Origins 3. Proceedings of the Third International Conference "Origin of the State. Predynastic and Early Dynastic Egypt", London, $27^{\text {th }}$ Fuly $-1^{\text {st }}$ August 2008, (Orientalia Lovaniensia Analecta 205), Leuven, Paris, Walpole: 157-191.

Gellner, E.; Waterbury, J. (eds.)

1977 Patrons and Clients in Mediterranean Societies. London.

Godenho, G.

2007 Manifestations of Elite Culture in Egypt's First Intermediate Period, Unpublished $\mathrm{PhD}$ Thesis, University of Liverpool.

GundLACH, R.

1988 “"Erschlagen des Feindes”: Der Krieg als politisches Mittel und kulturelles Problem im pharaonischen Ägypten“, in: H.H. Krummacher, (ed.): Geisteswissenschaften wozu?, Stuttgart: $245-65$.

HALL, E.S.

1986 The Pharaoh Smites his Enemies. A Comparative Study. München.

HeLGK, W.

1987 Untersuchungen zur Thinitenzeit. (Ägyptologische Abhandlungen 45). Wiesbaden.

HENDRICKX, S.

1998 "Peaux d'animaux comme symboles prédynastiques", Chronique d'Egypte 73: 203-230. 
Chiefs, Kings, and Patrons. Leadership and Social Logics in the Beginnings of Ancient Egypt Marcelo Campagno

2008 "Les grands mastabas de la $\mathrm{I}^{\mathrm{re}}$ dynastie à Saqqara", Archéo-Nil 18: 6o-88.

Huard, P.; Leclant, J.

1980 La Culture des Chasseurs du Nil et du Sahara. (Mémoires du Centre de Recherches Anthropologiques et Ethnographiques 29). Alger.

Jones, D.

2000 An Index of Ancient Egyptian Titles. Epithets and Phrases of the Old Kingdom. (BAR International Series 866). Oxford.

KLOTH, N.

2002 Die (auto-)biographischen Inschriften des ägyptischen Alten Reiches: Untersuchungen zu Phraseologie und Entwicklung. (Studien zur Altägyptischen Kultur Beihefte 8). Hamburg.

KÖHLER, E.CH.

2002 "History or Ideology? New Reflections on the Narmer Palette and the Nature of Foreign Relations in Pre- and Early Dynastic Egypt", in: E.C.M. van den Brink and Th.E. Levy (eds.): Egypt and the Levant. Interrelations from the $4^{\text {th }}$ through the Early $3^{\text {rd }}$ Millennium B.C.E., London, New York: 499-513.

2010 "Theories of State Formation", in: W. Wendrich (ed.): Egyptian Archaeology, Malden, Oxford, Chichester: 36-54.

LEHNER, M.

2000 "Fractal House of Pharaoh: Ancient Egypt as a Complex Adaptive System, a Trial Formulation", in: T.A. Kohler and G.J. Gumerman (eds.): Dynamics in Human and Primate Societies. Agent-based Modelling of Social and Spatial Processes, New York, Oxford: $275-353$.

Maisels, Ch.K.

1999 Early Civilizations of the World. The Formative Histories of Egypt, The Levant, Mesopotamia, India and China. London.

Midant-Reynes, B.

1992 Préhistoire de l'Égypte. Des premiers hommes aux premiers Pharaons. Paris.

2003 Aux origines de l'Égypte. Du Néolithique à l'émergence de l'État. Paris.
Mommsen, Th.

1985 Le Droit public romain, VII tomes. Paris (original edition 1891).

Moreno García, J.C.

1999 Hwt et le milieu rural égyptien du IIIe millénaire. Economie, administration et organisation territoriale. Paris.

2001 "Hq3w, "jefes, gobernadores", y élites rurales en el III milenio antes de Cristo. Reflexiones acerca de algunas estatuas del Imperio Antiguo", in: J. Cervelló Autuori and A.J. Quevedo Álvarez (eds.): ...ir a buscar leña. Estudios dedicados al Prof. Jesús López, (Aula Agyptiaca-Studia 2), Barcelona: 141-154.

2004 Egipto en el Imperio Antiguo (2650-2150 antes de Cristo). Barcelona.

2012 "Households", in: E. Frood and W. Wendrich (eds.): UCLA Encyclopedia of Egyptology. Los Angeles. http://digital2.library.ucla.edu/viewItem.do?ark=21198/ zzo02czxo7.

2013 'The 'Other' Administration: Patronage, Factions, and Informal Networks of Power in Ancient Egypt", in: J.C. Moreno García, (ed.): Ancient Egyptian Administration, (Handbuch der Orientalistik Section 1 104), Leiden, Boston: 1029-1065.

Morenz, L.D.

2009-2010 "Power and Status. Ankhtifi the Hero, founder of a New Residence?", in: J.C. Moreno García (ed.): Élites et pouvoir en Égypte ancienne, (Cahiers de Recherches de l'Institut de Papyrologie et d'Égyptologie de Lille 28), Lille: 177-192.

Orenstein, $\mathrm{H}$.

1980 "Asymmetrical reciprocity: A Contribution to the Theory of Political Legitimacy", Current Anthropology 21/1: 69-91.

Pérez Largacha, A.

1993 El nacimiento del Estado en Egipto. (Aegyptiaca Complutensia 2). Alcalá de Henares.

Petrie, W.M.F.

1900 The Royal Tombs of the First Dynasty, vol. I. (Egypt Exploration Fund Memoir 18). London. 
PoWell, J.D.

1970 "Peasant Society and Clientelistic Politics", The American Political Science Review 64: 411-425.

QUiBELL, J.E.

1900 Hierakonpolis I (Egyptian Research Account Memoir 4). London.

Quibell, J.E.; Green, F.W.

1902 Hierakonpolis II (British School of Archaeology in Egypt 5). London.

REDFord, S.; RedFord, D.B.

1989 "Graffiti and Petroglyphs Old and New from the Eastern Desert", Fournal of the American Research Center in Egypt 26: 3-49.

REISNER, G.A.

1932 A Provincial Cemetery of the Pyramid Age, $\mathrm{Na}$ ga-ed-Dêr. Oxford.

1936 The Development of the Egyptian Tomb down to the Accession of Cheops. Cambridge, Oxford, London.

RichaRds, J.

2005 Society and Death in Ancient Egypt. Mortuary Landscapes of the Middle Kingdom. New York.

Sahlins, M.

2011 "What kinship is (part one)", fournal of the Royal Anthropological Institute (N.S.) 17: 2-19.

Schenkel, W.

1965 Memphis-Herakleopolis-Theben. Die epigraphischen Zeugnisse der 7.-11. Dynastie Ägyptens. (Ägyptologische Abhandlungen 12). Wiesbaden.

SeIdlmayer, S.J.

1990 Gräberfelder aus dem Übergang von Alten zum Mittleren Reich. Studien zur Archäologie der Ersten Zwischenzeit. (Studien zur Archäologie und Geschichte Altägyptens 1). Heidelberg.

Sethe, K.

1933 Urkunden des Alten Reichs, vol. I. Leipzig.

SNAPE, S.

2011 Ancient Egyptian Tombs: The Culture of Life and Death. Malden, Oxford, Chichester.
STRUdwick, N.

2005 Texts from the Pyramid Age. (Writings of the Ancient World 16). Atlanta.

VANDIER, J.

1950 Mo'alla. La tombe d'Ankhtifi et la tombe de Sebekhotep. (Bibliothèque d'Étude 18). Le Caire.

1952 Manuel d'archéologie égyptienne, I: Les époques de formation. Paris.

VAudou, E.

2008 "Les sépultures subsidiaires des grandes tombes de la Ire dynastie égyptienne", Archéo-Nil 18: 148-165.

WENKE, R.J.

2009 The Ancient Egyptian State. The Origins of Egyptian Culture (c. $8000-2000$ BC). New York.

WestBRoOK, R.

2005 "Patronage in the Ancient Near East", Fournal of the Economic and Social History of the Orient 48: 210-233.

WiLKInson, T.A.H.

1996 State Formation in Egypt. Chronology and Society. (Cambridge Monographs in African Archaeology 40 / BAR International Series 651). Oxford.

1999 Early Dynastic Egypt. London.

2000 "Rock Drawings of the Eastern Desert. Survey Expedition December 1999", in: D. Rohl, (ed.): The Followers of Horus. Eastern Desert Survey Report, Vol. I, Abingdon: 158165 .

2002 "Reality versus ideology: The evidence for 'Asiatics' in Predynastic and Early Dynastic Egypt", in: E.C.M. van den Brink and Th.E Levy (eds.): Egypt and the Levant. Interrelations from the 4th through the early 3 rd Millennium B.C.E., London, New York: 514-520.

Willems, H.

2010 "The First Intermediate Period and the Middle Kingdom", in: A.B. Lloyd, (ed.): A Companion to Ancient Egypt, Malden, Oxford, Chichester: I, 81-100. 
Trabajos de Egiptología

Papers on Ancient Egypt 


\section{Consejo editorial}

\section{Director}

Miguel Ángel Molinero Polo

Universidad de La Laguna, Tenerife, Islas Canarias

\section{Secretaría de edición}

Lucía Díaz-Iglesias Llanos

Centro Superior de Investigaciones Científicas, Madrid

Alba María Villar Gómez

Universidad Autónoma de Madrid

\section{Colaborador de edición / English editorial assistant}

Kenneth Griffin

Swansea University, Gales, Reino Unido

\section{Consejo de redacción}

Antonio Pérez Largacha

Universidad de Castilla - La Mancha

José Ramón Pérez-Accino Picatoste

Universidad Complutense de Madrid

$M^{a}$ Covadonga Sevilla Cueva

Universidad Autónoma de Madrid

\section{Comité científico}

Josep Cervelló Autuori

Universitat Autònoma de Barcelona

María José López-Grande

Universidad Autónoma de Madrid

Josep Padró i Parcerisa

Universitat de Barcelona

M. ${ }^{a}$ Carmen Pérez Die

Museo Arqueológico Nacional, Madrid

Esther Pons Mellado

Museo Arqueológico Nacional, Madrid

José Miguel Serrano Delgado

Universidad de Sevilla 
Trabajos de Egiptología

Papers on Ancient Egypt

Número 7

2016 
Trabajos de Egiptología está producida por

Isfet. Egiptología e Historia

con la colaboración del Centro de Estudios Africanos

de la Universidad de La Laguna

C/ Blanco 1, $2^{\circ}$

38400 Puerto de la Cruz

Tenerife-Islas Canarias

España

(C) De los textos: sus autores y Trabajos de Egiptología

Diseño de arte y maquetación

Marian Montesdeoca y Ulises Ramos

info@marianmontesdeoca.com

Imprime: Gráfica Los Majuelos

Depósito Legal: TF 935-2015

ISSN: 1695-4750 


\section{Contents}

$\begin{array}{ll}\text { Prefacio/Foreword } & 7\end{array}$

Chiefs, Kings, and Patrons. Leadership and Social Logics in the Beginnings of Ancient Egypt 9 Marcelo CAMPAGNO

The Development of Local Osirian Forms. An Explanatory Model

Lucía DÍAZ-IGLESIAS LLANOS

Shaushka, the Traveling Goddess

Graciela GESTOSO SINGER

What are we Talking about when we Talk about Memphis?

Maria Helena Trindade LOPES

Stone Vessels of Egyptian Appearance from Ibiza

67

María José LÓPEZ-GRANDE

The Argentine Archaeological Mission at Tell el-Ghaba. A Third Intermediate-Early Saite Period Site on the Ancient Egyptian Eastern Border. Remarks and Main Results Silvia LUPO

TT 209. Objectives of the proyecto dos cero nueve and the Name of the Tomb Owner Miguel Ángel MOLINERO POLO

The Herakleopolis Magna Project (Ehnasya el Medina). Summary and Results of Work 2000-2015

Tombs of the Roman Period in Sector 26 of the High Necropolis Archaeological Site of Oxyrhynchus, El-Bahnasa

Esther PONS MELLADO

The Decoration of the Pronaos of Petosiris' Tomb. Themes, Scenes, Styles and Techniques José das Candeias SALES

The Artist in his Context: New Tendencies on the Research of Ancient Egyptian Art Inmaculada VIVAS SÁINZ 